Jelena Šakotić-Kurbalija*

UDK 159.944:316.811/.815(497.11)

Biljana Trifunović

DOI: $10.19090 / \mathrm{gff} .2017 .2 .361-378$

Filozofski fakultet

Originalni naučni rad

Univerzitet u Novom Sadu

\title{
POLNE RAZLIKE U STRATEGIJAMA SUOČAVANJA SA STRESOM KOD BRAČNIH PARTNERA U SRBIJI ${ }^{* *}$
}

*jelenasakotickurbalija@ff.uns.ac.rs

** Istraživanje prikazano ovim radom predstavlja deo projekta "Efekti egzistencijalne nesigurnosti na pojedinca i porodicu u Srbiji", koji finansira Ministarstvo prosvete i nauke Republike Srbije (DN 179022). Podaci prikupljeni na istom uzorku ispitanika su korišćeni i u sledećim radovima:

Šakotić-Kurbalija, J., i Kurbalija D. (2015). Kvalitet bračnih odnosa u Srbiji iz ženskog i muškog ugla. Peti kongres psihoterapeuta Srbije: Ljubav i psihoterapija. Beograd: 22.10 -25. 10. 2015. Savez društava psihoterapeuta Srbije, Zbornik rezimea na CD-u, 134.

Kurbalija D., Šakotić-Kurbalija, J., Strizović, I., i Trifunović, B. (2015). Bačni parovi u Srbiji: Kako muškarci vide sebe, a kako ih vide žene. Peti kongres psihoterapeuta Srbije: Ljubav i psihoterapija. Beograd: 22.10 -25. 10. 2015. Savez društava psihoterapeuta Srbije, Zbornik rezimea na CD-u, 84-85.

Šakotić-Kurbalija, J., Kurbalija D., Trifunović, B., i Strizović, I. (2015). Bačni parovi u Srbiji: Kako žene vide sebe, a kako ih vide muškarci. Peti kongres psihoterapeuta Srbije: Ljubav i psihoterapija. Beograd: 22.10 -25. 10. 2015. Savez društava psihoterapeuta Srbije, Zbornik rezimea na CD-u, 133-134.

Strizović, I., i Šakotić-Kurbalija, J. (2016). Povezanost percepcije partnerove komunikacijske kompetencije sa opštim bračnim zadovoljstvom. Šesti kongres psihoterapeuta Srbije: Društvo i psihoterapija. Beograd: 20.10 -23. 10. 2016. Savez društava psihoterapeuta Srbije, Zbornik rezimea na CD-u, 21.

Šakotić-Kurbalija, J., i Kukulj, N. (2016). Povezanost kvaliteta bračnog odnosa i potencijala za razvod sa podelom odgovornosti među partnerima. Šesti kongres psihoterapeuta Srbije: Društvo i psihoterapija. Beograd: 20.10 -23. 10. 2016. Savez društava psihoterapeuta Srbije, Zbornik rezimea na CD-u, 20.

Šakotić-Kurbalija, J., Kurbalija D., i Kapetan, A. (2016). Razlike između muškaraca i žena u predikciji potencijala za razvod na osnovu bračnog kvaliteta. Šesti kongres psihoterapeuta Srbije: Društvo i psihoterapija. Beograd: 20.10 -23. 10. 2016. Savez društava psihoterapeuta Srbije, Zbornik rezimea na CD-u, 21-22. 
U cilju utvrđivanja značajnosti polnih razlika u korišćenju strategija suočavanja sa stresom generalno, prikupljeni su podaci na uzorku od 446 bračnih parova različitih sociodemografskih karakteristika, starosti 17-81 god. Za ispitivanje strategija suočavanja sa stresom, primenjena je Brief COPE skala (Carver, 1997). Jednofaktorskom multivarijatnom analizom varijanse su ispitane polne razlike u 14 strategija suočavanja sa stresom: samoometanje, aktivno prevladavanje, poricanje, zloupotreba psihoaktivnih supstanci, traženje emocionalne i instrumentalne podrške, odustajanje, ventiliranje, pozitivno redefinisanje, planiranje, humor, prihvatanje, religioznost i samookrivljivanje. Rezultati ukazuju da bračni partneri sa jednakom učestalošću koriste mnoge strategije suočavanja sa stresom, ali i da postoje polne razlike (sa malim efektom) u učestalosti korišćenja specifičnih strategija - samoometanju, traženju emocionalne podrške, traženju instrumentalne podrške, ventiliranju, planiranju i religioznosti, pri čemu žene na ovim dimenzijama postižu više skorove $u$ odnosu na svoje partnere. Dobijeni rezultati su $u$ saglasnosti sa rezultatima novijih istraživanja koja sugerišu sve veće smanjenje polnih razlika u učestalosti korišćenja specifičnih strategija suočavanja sa stresom, pri čemu se sve veći značaj u izboru strategija suočavanja sa stresom pripisuje socijalnom kontekstu. Budući da se strategije suočavanja sa stresom u mnogim istraživanjima izdvajaju kao prediktori generalnog bračnog funkcionisanja, njihovo istraživanje jeste izuzetno značajno za razumevanje bračne dinamike i karakteristika bračnog odnosa.

Ključne reči: strategije suočavanja, stres, bračni parovi, Brief COPE skala, polne razlike

\section{UVOD}

Kako decenijama unazad pokazuju nalazi brojnih istraživanja sprovedenih u različitim državama i različitim kulturama (npr., Fowers, 1991; Maddock, Hogan, Antonov, \& Mastkovsky, 1994; Shek, 1995; Ragsdale, 1996; Kitamura at al., 1998; Schumm, Resnick, Bollman, \& Jurich, 1998; Ballard-Reisch \& Weigel, 1999; Rosnati \& Ranieri, 2000; Vannoy \& Cubbins, 2001), a to podržavaju i nalazi istraživanja sprovedenih u našem regionu (npr. Jaramaz, 2010; Ilić, 2011; Huić, Kamenov, \& Mihić, 2012; Šakotić-Kurbalija i Kurbalija, 2015), u proseku, žene percipiraju značajno nižim kvalitet bračnog odnosa, u odnosu na doživljaj koji imaju muškarci (i to na svakoj ispitanoj dimenziji kvaliteta bračnog odnosa -

Trifunović, B., Šakotić-Kurbalija, J., i Strizović I. (2016). Razlike u percepciji bračnog kvaliteta među parovima različitih kombinacija obrazaca partnerske afektivne vezanosti. Primenjena psihologija, 9(3), 313-332.

Šakotić-Kurbalija, J. (2016). Bračni odnosi u Srbiji: povezanost kvaliteta, potencijala za razvod $i$ spremnosti za traženje psihološke pomoći. Novi Sad: Filozofski fakultet.

$\mathrm{Ni}$ u jednom od navedenih radova nisu prikazani rezultati vezani za istraživački problem ovog rada. 
Konsenzusu, Kohezivnosti, Zadovoljstvu brakom i Afektivno-seksualnoj usaglašenosti, te su i generalno nezadovoljnije brakom).

Važno je imati u vidu i nalaze da postoje značajne razlike između žena i muškaraca po pitanju vrste negativnih životnih događaja koji najviše utiču na doživljaj smanjenja kvaliteta bračnog odnosa - kod žena su to prvenstveno negativni događaji vezani za brak i porodicu, a kod muškaraca negativni događaji na poslu i finansijski problemi (Conger, Lorenz, Elder, Simons, \& Ge, 1993). Nalazi istraživanja, pritom, ukazuju da žene, u poređenju sa muškarcima, uočavaju znatno veći broj problema u braku, te se i češće žale na bračne probleme; dok muškarci mnoge bračne probleme ne uočavaju ili ih smatraju nevažnim (Thompson \& Walker, 1989; Amato \& Rogers, 1997).

Bračno nezadovoljstvo se povećava kada supružnici uđu u roditeljske uloge, i to posebno kod žena (Ade-Ridder \& Brubaker, 1983; Belsky, Spanier, \& Rovine, 1983; Belsky, Lang, \& Rovine, 1985; Belsky \& Pensky, 1988; Nomaguchi \& Milkie, 2003), a različiti autori vide uzroke većeg bračnog nezadovoljstva žena u njihovoj većoj opterećenosti različitim ulogama i svakodnevnim aktivnostima. Reč je o tome da žene, pored bračne i profesionalne uloge, najčešće preuzimaju i najveći deo odgovornosti za obavljanje svakodnevnih kućnih poslova i brigu o deci (Taylor, Bennett \& Sung, 2010), što doprinosi razvoju većeg nivoa njihovog distresa, depresije i anksioznosti, u odnosu na muškarce (Barnett, 2004).

Istraživanja sprovedena $u$ našoj sredini, takođe, pokazuju da su žene značajno više od muškaraca uključene u svakodnevne poslove u domaćinstvu i u staranje o deci (Mihić i Zotović, 2011; Mihić, Zotović, i Petrović, 2006; Petrović, 2007; Petrović, Mihić, Zotović, i Kapor-Stanulović, 2009). Međutim, u nekim novijim istraživanjima, takođe sprovedenim u našoj sredini, utvrđeno je da najveći broj i muškaraca i žena, pri raspodeli poslova u domaćinstvu izjavljuje da oboje jednako učestvuju u brizi o deci i u donošenju odluka vezanih za decu, a pritom se raspodela poslova $\mathrm{u}$ domaćinstvu nije pokazala kao dobar prediktor ni percepcije bračnog kvaliteta, ni potencijala za razvod (Šakotić-Kurbalija, 2016; ŠakotićKurbalija i Kukulj, 2016).

Rezultati različitih istraživanja (npr. Hobfoll, Dunahoo, Ben-Porath, \& Monnier, 1994; Bouchard, Sabourin, Lussier, Wright, \& Richer, 1998), takođe, ukazuju da muškarci i žene koriste različite strategije kada se suočavaju sa bračnim problemima. Pri tom, muškarci u većoj meri pokušavaju da utiču na uzroke stresa, ali su istovremeno i skloniji odustajanju od pokušaja da se izbore sa problemima ukoliko njihovi napori ne daju brzo rezultate (Veroff, Kulka, \& Douvan, 1981; Stone \& Neale, 1984), dok su ženama, u proseku, svojstveniji prilagođavanje novonastalim okolnostima, ublažavanje negativnih posledica stresa i oslobađenje od 
emocionalne napetosti, te traženje i oslanjanje na pomoć drugih ljudi i institucija u pokušajima da se izbore sa stresom (Folkman \& Lazarus, 1980; Billings \& Moos, 1981; Stone \& Neale, 1984; Hamilton \& Fagot, 1988).

Prema rezultatima nekih istraživanja, u situacijama suočavanja sa bračnim problemima, žene izveštavaju o većoj brizi, konfliktima i traženju različitih aktivnosti van bračnog odnosa, što predstavlja aktivan napor čija je svrha udaljavanje od problema i njihovo zaboravljanje, a doprinosi razvoju nižeg bračnog zadovoljstva (npr. Billings \& Moos, 1981; Stone \& Neale, 1984; Hamilton \& Fagot 1988; Hobfoll, et al., 1994). Pri tom, ista istraživanja ukazuju da suočavanje sa stresom kod žena koje predstavlja pribegavanje emocionalnim odgovorima na probleme i provođenje vremena u diskusiji sa prijateljima ili porodicom o problemima, za posledicu najčešće ima visoko zadovoljstvo bračnim odnosom (Billings \& Moos, 1981; Stone \& Neale, 1984; Hamilton \& Fagot 1988).

Neki autori, međutim, ističu da žene mogu imati kratkoročnu dobrobit kada koriste strategije poricanja (npr. Bouchard et al., 1998). Tome u prilog govore i nalazi istraživanja u našoj sredini - da je bračno zadovoljstvo žena u pozitivnoj korelaciji sa sklonošću ka poricanju postojanja problema (Šakotić-Kurbalija, 2011). Pored toga, rezultati jedne opsežne metaanalize koja je obuhvatila 50 različitih studija koje su se bavile razlikama među polovima u strategijama suočavanja sa stresom sprovedenih u periodu između 1990. i 2000. godine (Tamres, Janicki \& Helgeson 2002) ukazuju na to da žene češće od muškaraca koriste gotovo sve strategije suočavanja sa stresom (kako one usmerene na emocije, tako i one usmerene na problem). Pritom razlike koje su registrovane u okviru nekih studija nisu potvrđene nalazima drugih istraživanja, a veličine efekta za 17 testiranih strategija suočavanja sa stresom u većini slučajeva su bile realtivno male, čak i kada su bile statistički značajne (Tamres, Janicki \& Helgeson 2002). Najnovija istraživanja, takođe, sugerišu sve slabiju izraženost polnih razlika u izboru strategija suočavanja sa stresom, što se interpretira sve većim socijalnim promenama (Cooper \& Quick, 2017)

Imajući u vidu nalaze stranih istraživanja koja ukazuju da se žene, u poređenju sa muškarcima, češće žale na probleme u braku i da uočavaju više bračnih problema (Amato \& Rogers, 1997), da fiziološki znatno snažnije od muškaraca reaguju na promene u bračnom odnosu (Hibbard \& Pope, 1993; Acitelli \& Young, 1996; Gallo, Troxel, Matthews, \& Kuller, 2003), te da je bračno zadovoljstvo žena značajnije za stabilnost braka od bračnog zadovoljstva muškaraca (Heaton \& Blake, 1999) dosadašnja istraživanja, u oblasti bračnih odnosa u Srbiji, bila su usmerena samo na ispitivanje strategija suočavanja sa stresom u populaciji 
žena (Šakotić-Kurbalija, 2011; Šakotić-Kurbalija, Šanta i Kurbalija, 2016; ŠakotićKurbalija, Trifunović, i Zotović, 2016).

Mada je i u našoj sredini potvrđeno da su žene manje zadovoljne brakom i da znatno lošijim percipiraju kvalitet bračnog odnosa, na svakoj od ispitivanih dimenzija (Šakotić-Kurbalija i Kurbalija, 2015); nalazi istraživanja sprovedenog na bračnim parovima u Srbiji (Šakotić-Kurbalija, Kurbalija, i Kapetan, 2016) nisu potvrdili inostrane nalaze da je bračno zadovoljstvo žena značajnije za stabilnost braka, od bračnog zadovoljstva muškaraca (Heaton \& Blake, 1999). Istraživanjem u našoj sredini je utvrđeno da je kod muškaraca izraženija povezanost između percepcije bračnog kvaliteta i potencijala za razvod (25\% zajedničke varijanse), nego kod žena (19\% zajedničke varijanse), a pritom je bračno (ne)zadovoljstvo i kod jednih i kod drugih glavni pojedinačni prediktor potencijala za razvod (ŠakotićKurbalija, Kurbalija, i Kapetan, 2016). Imajući ovo u vidu, značajno je proveriti i koliko se nalazi inostranih istraživanja vezanih za polne razlike u strategijama suočavanja sa stresom, kod bračnih partnera, mogu koristiti za razumevanje funkcionisanja bračnih odnosa u Srbiji. Odnosno, značajno je utvrditi postoje li i kakve su (ukoliko postoje) polne razlike u strategijama suočavanja sa generalnim stresom kod bračnih partnera u Srbiji!?

\section{METOD}

\section{Uzorak}

Istraživanjem je obuhvaćeno 446 bračnih parova koji žive u Srbiji. Ispitivanje je bilo anonimno i dobrovoljno. Ispitanici su dobili mušku i žensku formu baterije testova koje su popunjavali samostalno kod kuće, kao i po dve prazne koverte u kojima su vraćali popunjene upitnike ispitivaču. Ispitanici su imali zadatak da se prisete stresnih događaja koje su iskusili u proteklih nekolika meseci, te da izveste o učestalosti korišćenja navedenih strategija za prevazilaženje stresa.

Starost ispitanica u uzorku se kretala između 17 i 79 godina $(A S=39.49$, $S D=11.21)$, dok se starost njihovih partnera kretala između 20 i 81 godine $(A S=$ $40.21, S D=11.61)$. Od ukupnog broja ispitanih parova $77,3 \%$ je venčano, a $69,7 \%$ parova ima decu. Parovi žive zajedno od 11 meseci do 57 godina $(A S=14.15, S D=$ 11.79).

Istraživanjem su obuhvaćeni ispitanici različitog obrazovnog, radnog $\mathrm{i}$ socioekonomskog statusa. U uzorku su zabeležene značajne polne razlike u stepenu stručne spreme $\left(\chi^{2}(5)=18.89, p<.05\right)$, pri čemu ispitanice imaju viši obrazovni status u odnosu na svoje partnere; najveći broj muških ispitanika ima završenu 
srednju školu (46,8\%), dok najveći broj ženskih ispitanika ima završenu visoku školu/fakultet $(43,3 \%)$. Polne razlike u radnom statusu nisu zabeležene $\left(\chi^{2}(6)=\right.$ 9.88, $p>$.05); približno jednak broj i muških i ženskih ispitanika je u radnom odnosu (54\% ispitanica i 55\% ispitanika). Takođe, najveći i približno jednak broj ispitanika i ispitanica procenjuje svoj socioekonomski status kao prosečan $(49,6 \%$ ispitanica i 49,2\% ispitanika).

\section{Instrumenti}

Brief COPE skala (Carver, 1997) je primenjena za ispitivanje strategija suočavanja sa stresom. Skala se sastoji iz 28 ajtema koji predstavljaju opise različitih ponašanja u stresnim situacijama. Od ispitanika se traži da se prisete stresnih situacija koje su se dogodile u poslednjih nekoliko meseci, a zatim da procene učestalost svog ponašanja (nikada, retko, ponekad i često) na dati način, $u$ cilju prevladavanja stresa. Ovom skalom se procenjuje 14 načina suočavanja sa stresom: samoometanje, aktivno prevladavanje, poricanje, zloupotrebu psihoaktivnih supstanci (PAS), traženje emocionalne podrške, traženje instrumentalne podrške, odustajanje, ventiliranje, pozitivno redefinisanje, planiranje, humor, prihvatanje, religioznost i samookrivljivanje. Pouzdanost instrumenta je zadovoljavajuća, vrednosti Crobachovih alfa koeficijenata se kreću između .68 i .84 .

\section{REZULTATI}

U Tabeli 1 su prikazani deskriptivni pokazatelji za sve subskale Brief COPE skale. Prema blažem kriterijumu (-2/+2), vrednosti skjunisa i kurtozisa se mogu smatrati prihvatljivim za sve subskale navedenog upitnika (Finney \& DiStefano, 2006).

Tabela 1

Deskriptivni pokazatelji za subskale Brief COPE skale na muškom i ženskom uzorku $(N=446)$

\begin{tabular}{lccccccccccc}
\hline \multirow{2}{*}{ Subskala } & & \multicolumn{4}{c}{ Muški pol } & \multicolumn{4}{c}{ Ženski pol } \\
\cline { 3 - 11 } & Min & Max & $A S$ & SD & Sk. & Kurt. $A S$ & SD & Sk. & Kurt. \\
\hline Samoometanje & 2 & 8 & 5.97 & 1.44 & -.58 & -.09 & 6.32 & 1.28 & -.54 & .03 \\
Aktivno & 2 & 8 & 6.86 & 1.19 & -1.14 & 1.34 & 6.87 & 1.12 & -.88 & .69 \\
prevladavanje & 2 & 8 & 4.03 & 1.72 & -.44 & -.79 & 4.20 & 1.75 & .32 & -.92 \\
Poricanje & 2 & 8 & 3.04 & 1.58 & 1.40 & .92 & 2.76 & 1.38 & 1.8 & 1.9 \\
Zloupotreba PAS & 2 & & & & & & & &
\end{tabular}




\begin{tabular}{|c|c|c|c|c|c|c|c|c|c|c|}
\hline $\begin{array}{l}\text { Traženje } \\
\text { emocionalne } \\
\text { podrške }\end{array}$ & 2 & 8 & 5.69 & 1.69 & -.49 & -.43 & 6.22 & 1.52 & -.69 & -.05 \\
\hline $\begin{array}{l}\text { Traženje } \\
\text { instrumentalne } \\
\text { podrške }\end{array}$ & 2 & 8 & 5.28 & 1.63 & -.30 & -.49 & 5.79 & 1.54 & -.41 & -.34 \\
\hline Odustajanje & 2 & 8 & 3.35 & 1.56 & .84 & -.42 & 3.43 & 1.54 & .77 & -.27 \\
\hline $\begin{array}{l}\text { Ventiliranje } \\
\text { (ispoljavanje neg. } \\
\text { osećanja) }\end{array}$ & 2 & 8 & 4.72 & 1.54 & -.46 & .11 & 5.28 & 1.44 & -.08 & -.39 \\
\hline $\begin{array}{l}\text { Pozitivno } \\
\text { redefinisanje } \\
\text { (reinterpretacija) }\end{array}$ & 2 & 8 & 6.60 & 1.32 & -.95 & .74 & 6.73 & 1.22 & -.93 & .77 \\
\hline Planiranje & 2 & 8 & 5.74 & 1.26 & -.05 & -.22 & 6.07 & 1.32 & -.40 & -.23 \\
\hline Humor & 2 & 8 & 5.63 & 1.76 & -.52 & -.48 & 5.56 & 1.77 & -.35 & -.73 \\
\hline $\begin{array}{l}\text { Prihvatanje } \\
\text { (rezigniranost) }\end{array}$ & 2 & 8 & 6.49 & 1.29 & -.80 & .44 & 6.49 & 1.17 & -.76 & .89 \\
\hline Religioznost & 2 & 8 & 3.98 & 1.93 & .67 & -.20 & 4.59 & 1.96 & .25 & -1.09 \\
\hline Samookrivljavanje & 2 & 8 & 4.74 & 1.53 & .02 & -.52 & 4.83 & 1.58 & .15 & -.66 \\
\hline
\end{tabular}

Napomena : Sk-skjunis; Kurt-kurtosis.

Jednofaktorskom MANOVA-om istražene su polne razlike $u$ domenu strategija suočavanja sa stresom. Preliminarnim ispitivanjem proverene su pretpostavke o normalnosti, linearnosti, univarijatnim i multivarijatnim autlajerima, homogenosti matrica varijanse - kovarijanse i multikolinearnosti. Nije registrovano ozbiljnije narušavanje pretpostavki, izuzev pretpostavke o jednakosti varijanse promenljivih: Poricanje, Korišćenje psihoaktivnih supstanci i Prihvatanje, te je za ove varijable korišćen stroži nivo značajnosti univarijatnih $F$-testova, tj. $p<.025$ (Tabachnick \& Fidell, 2007).

Rezultati pokazuju da su glavni efekti pola $\left(F(14,890)=7.53, p<.001, \eta_{\mathrm{p}}{ }^{2}\right.$ $=$.106) značajni na multivarijantnom nivou. Statističku značajnost (po Bonferronijevom prilagođenom nivou značajnosti od $p<.001$ ), sa malim efektom razlike (Cohen, 1988), dosegle su promenljive: Samoometanje, Traženje emocionalne podrške, Traženje instrumentalne podrške, Ventiliranje, Planiranje i Religioznost (Tabela 2), pri čemu ispitanice na ovim dimenzijama postižu više skorove. 
Tabela 2

Polne razlike na subkalama Brief COPE skale: univarijatni efekti

\begin{tabular}{llcccc}
\hline Faktor & Subskala & $\mathrm{F}$ & $\mathrm{df}_{1}$ & $\mathrm{p}$ & $\eta \mathrm{p}^{2}$ \\
\hline \multirow{4}{*}{ Pol } & Samoometanje & 17.521 & 1 & .000 & .019 \\
& Aktivno prevladavanje & .003 & 1 & .959 & .000 \\
& Poricanje & 3.091 & 1 & .079 & .003 \\
& Zloupotreba PAS & 7.135 & 1 & .008 & .008 \\
& Traženje emocionalne podrške & 24.921 & 1 & .000 & .027 \\
& Traženje instrumentalne podrške & 23.610 & 1 & .000 & .025 \\
& Odustajanje & 1.576 & 1 & .210 & .002 \\
& Ventiliranje & 35.93 & 1 & .000 & .038 \\
& Pozitivno redefinisanje & 2.786 & 1 & .095 & .003 \\
& Planiranje & 14.703 & 1 & .000 & .016 \\
& Humor & .051 & 1 & .821 & .000 \\
& Prihvatanje & .026 & 1 & .873 & .000 \\
& Religioznost & 28.118 & 1 & .000 & .025 \\
& Saamookrivljavanje & 1.532 & 1 & .216 & .002 \\
\hline
\end{tabular}

\section{DISKUSIJA}

Rezultati sprovedene studije ukazuju na to da bračni partneri sa jednakom učestalošću koriste mnoge strategije suočavanja sa stresom, ali i da postoje polne razlike u učestalosti korišćenja specifičnih strategija, pri čemu je efekat registrovanih polnih razlika mali. Dobijeni rezultati su u saglasnosti sa rezultatima nekih novijih istraživanja koja sugerišu sve veće smanjenje polnih razlika u izboru strategija suočavanja sa stresom, pri čemu se kao objašnjenje sve manje izraženih polnih razlika navode sve veće socijalne promene, odnosno, ističe se važnost konteksta u izboru strategija suočavanja sa stresom (Cooper \& Quick, 2017).

U većini prethodno sprovedenih istraživanja, izveštava se o učestalijem korišćenju strategija usmerenih na emocije kod žena, odnosno učestalijem korišćenju strategija usmerenih na problem kod muškaraca (npr. Matud, 2004; Eaton \& Bradley, 2008). Rezultati našeg istraživanja su u suprotnosti sa rezultatima prethodno pomenutih studija. Naime, u ovom istraživanju žene koriste učestalije i pojedine strategije usmerene na emocije, i pojedine strategije usmerene na problem. Objašnjenje ovakvih nalaza se možda može pronaći u samoj prirodi uzorka. Naime, prema situacionoj hipotezi (Rosario, Shinn, Morch, \& Huckabee, 1988), reakcije na stres su uslovljene vrstom stresora sa kojima se individue suočavaju, što znači da ukoliko su osobe izložene identičnom stresoru, ne postoje polne razlike u njihovim reakcijama. Dakle, prema ovoj pretpostavci izbor strategija suočavanja će biti 
uslovljen tipom stresora. Iako ovim istraživanjem nije ispitivano prevladavanje specifično stresora koji imaju poreklo u samoj relaciji, bračni parovi su često izloženi istim stresorima, bilo da stres ima poreklo u samoj relaciji ili je posledica spoljašnjih stresora koji utiču na oba partnera, te na taj način postoji mogućnost da je priroda uzorka dovela do izostanka očekivanih polnih razlika u korišćenju strategija usmerenih na emocije i strategija usmerenih na problem. Takođe, izostanak značajnih razlika $u$ ovoj studiji se može objasniti i sa drugog metodološkog aspekta, budući da je grupa strategija usmerenih na emocije izuzetno heterogena grupa, te se npr. u jednoj studiji (Rosario at al., 1988) pod ovim strategijama podrazumevaju humor, odmor, fizička aktivnost, druženje itd., dok se u drugoj studiji (Folkman \& Lazarus, 1985) pod istim strategijama navode samoobmana, pozitivno razmišljanje, samooptuživanje itd. (Tamres, Janicki, \& Helgeson, 2002).

Dobijene razlike u učestalosti korišćenja specifičnih strategija suočavanja sa stresom, kako onih usmerenih na emocije, tako i onih usmerenih na problem, se mogu objasniti na različite načine, i korišćenjem različitih koncepata. Strategije traženja instrumentalne i emocionalne podrške, kao i ventiliranje, bi se mogle grupisati u kategoriju strategija koje uključuju podršku od strane drugih osoba. Ovakvom kategorizacijom, dobijeni rezultati su u skladu sa rezultatima prethodnih istraživanja, u kojima se identifikuju značajne polne razlike u domenu socijalne podrške, pri čemu žene, u poređenju sa muškarcima, češće traže i dobijaju podršku od drugih osoba. U ovim studijama, dobijene razlike se objašnjavaju efektima socijalizacije i različitim rodnim ulogama koje naglašavaju autonomiju i nezavisnost kod muškaraca i socijalne relacije kod žena (Zuckerman \& Gagne, 2003). Međutim, u ovoj studiji ne može se u potpunosti primeniti isti način rezonovanja, budući da polne razlike u korišćenju nekih aktivnih i nezavisnih strategija ili nisu registrovane, ili polne razlike postoje, ali u korist žena (npr. kod planiranja). U skladu sa prethodno navedenim, kao prikladnije objašnjenje bi mogla poslužiti sama veličina socijalne mreže i dostupnost socijalnih izvora podrške. Naime, istraživanja dosledno ukazuju na to da žene, od adolescencije do starog doba, imaju više socijalnih izvora podrške, kao i da češće traže i dobijaju podršku, u poređenju sa muškarcima (Burda, Vaux, \& Schill, 1984; Heaney \& Israel, 2008). Što je veći broj ljudi koji mogu pružiti podršku osobi, ova strategija će češće biti korišćena kada se ukaže potreba za njom. Dakle, u zavisnosti od tipa stresora i procene potrebnih resursa za prevladavanje stresa, žene mogu koristiti nezavisne strategije suočavanja sa stresom, ali mogu tražiti i podršku od osoba iz svoje socijalne mreže. 
Takođe, istraživanja u domenu partnerskih relacija ukazuju na to da žene češće pružaju podršku svojim bračnim partnerima u stresnim situacijama. Tako npr. rezultati jednog istraživanja ukazuju na to da žene često preuzimaju dodatne poslove u domaćinstvu kada njihov partner doživljava stres na radnom mestu (Bolger, DeLongis, Kessler, \& Wethington, 1989). Dakle, čini se da su žene veštije od muškaraca u pružanju kako emocionalne, tako i instrumentalne podrške svojim partnerima. Budući da muškarci dobijaju potrebnu emocionalnu i instrumentalnu podršku od svojih partnerki, pretpostavlja se da oni imaju manju potrebu za traženjem ove vrste podrške, kako od svojih partnerki, tako i od drugih osoba. S druge strane, izostanak podrške od strane partnera, povećava potrebu žena za traženjem podrške od partnera, a zatim i od drugih osoba u socijalnoj mreži, ukoliko potrebe za podrškom nisu zadovoljene od strane partnera.

Identifikovane polnih razlika u samoometanju i religioznosti, kao strategijama suočavanja sa stresom, su u saglasnosti sa rezultatima istraživanja $u$ kojima se izveštava da žene češće koriste izbegavanje kao strategiju suočavanja sa stresnim situacijama, budući da samoometanje predstavlja aktivni, a religioznost pasivni oblik izbegavanja. Kada se razmatraju identifikovane polne razlike u samoometanju, za potencijalno objašnjenje dobijenih razlika može poslužiti kvantitet aktivnosti koje žene, naročito u braku, imaju. Naime, kako istraživanja i u našoj sredini pokazuju, žene su uključene u značajno većem stepenu u obavljanju svakodnevnih poslova u domaćinstvu i u staranje o deci, u odnosu na svoje partnere (npr. Petrović, Mihić, Zotović i Kapor-Stanulović, 2009; Mihić i Zotović, 2011). Na ovaj način, ženama je na raspolaganju veći broj aktivnosti koje mogu poslužiti kao distraktori u procesu suočavanja sa stresom.

Rezultat da žene češće, u odnosu na svoje partnere, pribegavaju religioznim ritualima (molitvama, meditacijama), kao načinima suočavanja sa stresom, u saglasnosti su i sa rezultatima istraživanja koja su imala za cilj ispitivanje polnih razlika u uključenosti u religiozne rituale, pri čemu se navodi da su žene u većem stepenu uključene $\mathrm{u}$ verske aktivnosti, u poređenju sa muškarcima (npr. Loewenthal, MacLeod \& Marco Cinnirella, 2001). Dobijene razlike mogu biti posledica razlika u određenim dimenzijama ličnosti, koje u ovom istraživanju nisu uzete u razmatranje. Tako npr. rezultati jedne meta-studije (Saroglou, 2002) ukazuju na značajnu pozitivnu povezanost prijatnosti, savesnosti, ekstraverzije i neuroticizma sa religioznošću, dok rezultati druge, kroskulturalne studije, izveštavaju o polnim razlikama upravo na navedenim dimenzija ličnosti, pri čemu žene postižu više skorove na svim navedenim dimenzijama, u poređenju sa muškarcima (Schmitt, Realo, Voracek, \& Allik, 2008). 
Polne razlike u korišćenju planiranja, kao strategije suočavanja sa stresom, se takođe mogu objasniti uključivanjem dimenzija ličnosti. Naime, u meta-studiji koja je imala za cilj ispitivanje povezanosti učestalosti korišćenja različitih strategija i dimenzija ličnosti, dobijeni su rezultati koji sugerišu značajnu povezanost planiranja sa povišenom ekstraverzijom i savesnošću (Connor-Smith \& Flachsbart, 2007). Kao što je prethodno pomenuto, žene na ovim dimenzijama postižu veće skorove, te se na ovaj način može objasniti i veća učestalost korišćenja planiranja kao načina suočavanja sa stresnim situacijama kod žena, u odnosu na njihove partnere.

\section{ZAKLJUČAK}

Sprovedeno istraživanje, prikazano ovim radom, predstavlja polaznu osnovu za buduća istraživanja koja treba da ispitaju medijatorske i moderatorske uticaje različitih varijabli na odnos pola i strategija suočavanja sa stresom, kao npr. osobina ličnosti, budući da se u ovom istraživanju dobijene polne razlike $\mathrm{u}$ pojedinim strategijama suočavanja smisleno mogu objasniti uključivanjem ovih konstrukta. Takođe, u narednim studijama bi trebalo ispraviti i metodološke nedostatke ove studije. Budući da istraživanja ukazuju na to da izbor strategija suočavanja sa stresom zavisi od tipa stresora, procene stepena njegove opasnosti i stepena intenziteta doživljenog stresa (Tamres, Janicki \& Helgeson 2002), koje u ovom istraživanju nisu uzete u razmatranje, bilo bi značajno da naredne studije, pored ispitivanja konkretnih strategija suočavanja sa stresom, uključe informacije i o ovim varijablama, kako bi se dobili što precizniji i potpuniji rezultati. U budućim studijama bi tako bilo korisno razgraničiti tipove stresora na one koje imaju poreklo unutar i izvan same partnerske relacije, $s$ obzirom na to da u ovoj studiji nije specifikovan tip stresora na prethodno pomenuti način, što je moglo da se odrazi na izbor strategija prevladanja. Iako se kao metodološki nedostatak može navesti i prigodnost uzorka, obuhvatajući relativno veliki broj bračnih partnera različitih sociodemografskih karakteristika, ova studija ipak obezbeđuje generalizabilnost rezultata.

I pored prisutnih metodoloških ograničenja ove studije, ona daje značajan teorijski doprinos postojećim saznanjima $\mathrm{u}$ oblasti istraživanja polnih razlika $\mathrm{u}$ strategijama suočavanja sa generalnim stresom, zato što razmatra polne razlike u strategijama suočavanja sa stresom u novom kontekstu - kontekstu bračnih partnera. Trenutna studija predstavlja polaznu osnovu za buduća istraživanja polnih razlika u izboru strategija suočavanja sa stresom, kako generalnim, tako i bračnim, u kontekstu partnerskih relacija. Iako u ovom istraživanju nije ispitivan specifično 
stres koji ima poreklo u samoj partnerskoj relaciji, već stres generalno, spovedena studija ipak proširuje postojeća znanja o polnim razlikama o strategijama suočavanja sa stresom u kontekstu partnerskih relacija, budući da bračni status može imati efekte na izbor strategija suočavanja sa stresom generalno, u smislu da bračni partneri međusobno mogu uticati na izbor strategija suočavanja sa stresom koji ima poreklo i izvan same partnerske relacije, te tako npr., prisustvo bračnog partnera, njegove personalne karakteristike, izbor strategija suočavanja i sl., može smanjiti i/ili povećati učestalost korišćenja određenih strategija kod drugog partnera.

Pored, teorijskih, rezultati sprovedene studije daju i neke praktične implikacije. Strategije suočavanja sa stresom, kako onim koji ima svoje poreklo u samoj relaciji, tako i van nje, se u mnogim istraživanjima izdvajaju kao prediktori generalnog bračnog funkcionisanja (Papp \& Witt, 2010), te je ispitivanje različitih aspekata ovog konstrukta izuzetno značajno za razumevanje bračne dinamike i karakteristika bračnog odnosa. Kako su u ovom istraživanju identifikovane i sličnosti u učestalosti korišćenja određenih strategija suočavanja sa stresom, ali i razlike u učestalosti korišćenja specifičnih strategija između žena i njihovih partnera, možemo zaključiti da buduće programe i intervencije fokusirane na načine suočavanja i prevladavanja stresnih situacija, treba sprovoditi i na grupnom i na individualnom nivou. Naime, intervencije namenjene parovima bi se tako usmerile na razmatranje i izmenu disfunkcionalnih strategija suočavanja sa stresom, koje bračni partneri sa jednakom i velikom učestalošću koriste. Sa druge strane, individualne intervencije bi na drugačiji način pristupale izmeni disfunkcionalnih strategija i promovisanju funkcionalnih načina suočavanja sa stresnim situacijama, kod žena i muškaraca, u zavisnosti od toga na kojim strategijama su identifikovane polne razlike. Tako npr., kod žena bi se veća pažnja usmerila na promovisanje i podsticanje učestalijeg korišćenja strategija koje uključuju emocionalno i kognitivno procesiranje, nasuprot izbegavanju (kako pasivnom, tako i aktivnom, koje je u ovom istraživanju češće prisutno kod žena kao način suočavanja sa stresnim situacijama, u odnosu na njihove partnere). Muškarcima bi, sa druge strane, npr. više koristile intervencije namenjene podsticanju traženja pomoći, kako instrumentalne, tako i emocionalne u vidu podrške, saveta i utehe, od različitih osoba u svom okruženju - pored podrške koju dobijaju od svojih partnerki, ohrabrivalo bi se traženje pomoći i od prijatelja, članova porodice i naročito profesionalaca, budući da istraživanja ukazuju na to da su muškarci, u odnosu na žene, manje spremni da traže profesionalnu psihološku pomoć (Nam, Chu, Lee, Lee, Kim, \& Lee, 2010). 
Jelena Šakotić-Kurbalija, Biljana Trifunović

\section{SEX DIFFERENCES IN COPPING STRATEGIES AMONG MARITAL PARTNERS IN SERBIA}

\section{Summary}

Different factors have an influence on which coping strategies are used under different conditions, including sex. Sex differences are consistently reported in the coping literature, but in our country little attention has been given to examining possible distinctions in coping strategies, especially in the marital context, so the purpose of this study was to examine sex differences in coping strategies among marital partners. The data were collected among 446 married couples aged from 17 to $81(M=40.85, S D=11.48)$ with different sociodemographic characteristics (education, employment and socioeconomic status), who had lived together for between 11 months and 57 years $(M=14.15, S D=11.79)$. The participants responded to a coping questionnaire (Brief COPE scale, Carver, 1997) with the 14 subscales: self-distraction, active coping, denial, substance use, use of emotional support, use of instrumental support, behavioural disengagement, venting, positive reframing, planning, humour, acceptance, religion, and self-blame. To assess sex differences across the aforementioned coping strategies, the one-way MANOVA was performed. The results indicated that women used the strategies of self-distraction, emotional support requirement, instrumental support requirement, venting, planning and religion to a greater degree than their partners, but these differences have small effects. The obtained results are consistent with the results of recent studies which suggest a decrease in gender differences and emphasize the role of social changes and context in the choice of coping strategies. Contrary to the results of previous studies, the obtained results suggest that women use both emotionfocused strategies and problem-focused coping strategies as frequently as men. Explanations of these findings could potentially be found in the very nature of the sample and the consideration of the situational hypothesis, as well as in the variety of strategies that are considered as emotion-focused. In addition to the theoretical, the results of the conducted study have also some practical implications. Since many studies have identified coping strategies as predictors of general marital functioning, an examination of various aspects of this construct is extremely important for understanding the marital dynamics and characteristics of a relationship. Since this research identifies both similarities and differences in the frequency of using certain coping strategies, potential sex differences should be considered before planning any intervention or treatment focused on coping with stress, at both the individual and the couple level.

Keywords: sex differences, coping strategies, coping styles, married couples, Brief COPE scale

\section{LITERATURA}

Acitelli, L. K., \& Young, A. M. (1996). Gender and thought in relationships. In G. J. O. Fletcher, \& J. Fitness (Eds.), Knowledge structures in close relationships: A social psychological perspective (pp. 147-168). Mahwah, NJ: Erlbaum. 
Ade-Ridder, L. \& Brubaker, T. H. (1983.). The quality of long-term marriages. In T. H. Brubaker (Ed.), Family Relationships in Later Life (pp. 21-30). Beverly Hills, Sage Publications.

Amato, P. R., \& Rogers, S. J. (1997). A longitudinal study of marital problems and subsequent divorce. Journal of Marriage and the Family, 59, 612-624.

Ballard-Reisch, D. S., \& Weigel, D. J. (1999). Handbook of interpersonal commitment and relationship stability. Springer US.

Barnett, R. C. (2004). Women and multiple roles: Myths and reality. Harvard review of psychiatry, 12, 158-164.

Belsky, J., Lang, M. E., \& Rovine, M. (1985). Stability and change in marriage across the transition to parenthood: A second study. Journal of Marriage and the Family, 47, 855-865.

Belsky, J., \& Pensky, E. (1988). Marital change across the transition to parenthood. Marriage \& Family Review, 12, 133-156.

Belsky, J., Spanier, G. B., \& Rovine, M. (1983). Stability and change in marriage across the transition to parenthood. Journal of Marriage and the Family, 45, 567-577.

Billings, A. G., \& Moos, R. H. (1981). The role of coping responses and social resources in attenuating the stress of life events. Journal of behavioral medicine, 4, 139-157.

Bolger, N., DeLongis, A., Kessler, R. C., \& Wethington, E. (1989). The contagion of stress across multiple roles. Journal of Marriage and the Family, 51, 175-183.

Bouchard, G., Sabourin, S., Lussier, Y., Wright, J., \& Richer, C. (1998). Predictive validity of coping strategies on marital satisfaction: Cross-sectional and longitudinal evidence. Journal of Family Psychology, 12, 112-131.

Burda Jr, P. C., Vaux, A., \& Schill, T. (1984). Social support resources: Variation across sex and sex role. Personality and Social Psychology Bulletin, 10, 119-126.

Carver, C. S. (1997). You Want to Measure Coping But Your Protocol's Too Long: Consider the Brief COPE. International Journal of Behavioral Medicine, 4, 92-100.

Cohen, J. (1988). Statistical power analyses for the social sciences. Hillsdale, NJ, Lawrence Erlbauni Associates.

Conger, R. D., Lorenz, F. O., Elder, G. H., Jr., Simons, R. L., \& Ge, X. (1993). Husband and wife differences in response to undesirable life events. Journal of Health and Social Behavior, 34, 71-88. 
Connor-Smith, J. K., \& Flachsbart, C. (2007). Relations between personality and coping: a meta-analysis. Journal of personality and social psychology, 93, 1080-1118.

Cooper, C. L., \& Quick, J. C. (Eds.). (2017). The Handbook of Stress and Health: A Guide to Research and Practice. John Wiley \& Sons.

Eaton, R. J., \& Bradley, G. (2008). The role of gender and negative affectivity in stressor appraisal and coping selection. International Journal of Stress Management, 15, 94-115.

Finney, S. J., \& DiStefano, C. (2006). Non-normal and categorical data in structural equation modeling. In G. Hanchock \& R. Mueller (Eds.), Structural Equation Modeling: A second course (pp. 269-314). New York: Information Age Publishing, Inc.

Folkman, S., \& Lazarus, R. S. (1980). An analysis of coping in a middle-aged community sample. Journal of health and social behavior, 21, 219-239.

Fowers, B. J. (1991). His and her marriage: A multivariate study of gender and marital satisfaction. Sex Roles, 24, 209-221.

Gallo, L. C., Troxel, W. M., Matthews, K. A., \& Kuller, L. H. (2003). Marital status and quality in middle-aged women: Associations with levels and trajectories of cardiovascular risk factors. Health Psychology, 22, 453-463.

Hamilton, S., \& Fagot, B. I. (1988). Chronic stress and coping styles: A comparison of male and female undergraduates. Journal of personality and social psychology, 55, 819-823.

Heaney, C. A., \& Israel, B. A. (2008). Social networks and social support. Health behavior and health education: Theory, research, and practice, 4, 189-210.

Heaton, T. B., \& Blake, A. M. (1999). Gender differences in determinants of marital disruption. Journal of Family Issues, 20, 25-45.

Hibbard, J. H., \& Pope, C. R. (1993). Health effects of discontinuities in female employment and marital status. Social Science \& Medicine, 36, 1099-1104.

Hobfoll, S. E., Dunahoo, C. L., Ben-Porath, Y., \& Monnier, J. (1994). Gender and coping: The dual-axis model of coping. American journal of community psychology, 22, 49-82.

Huić, A., Kamenov, Ž., Jelić, M., Mihić, I., i Mihić, V. (2013). Slobodno vrijeme i zadovoljstvo brakom u Hrvatskoj i Srbiji - rodne i generacijske razlike. U I. Jerković, i Ž. Kamenov (Ur.), Vrednosti, stavovi i uloge: trangeneracijska perspektiva (str. 73-96). Novi Sad: Filozofski fakultet.

Ilić, Lj. (2011). Rodne razlike u izražavanju ljubavi: Efekti na zadovoljstvo brakom (Master rad). Filozofski fakultet, Univerzitet u Novom Sadu, Novi Sad. 
Jaramaz, O. (2010). Karakteristike i funkcionalnost bračnih relacija u Vojvodini. (Diplomski rad). Filozofski fakultet, Univerzitet u Novom Sadu, Novi Sad.

Kitamura, T., Aoki, M., Fujino, M., Ura, C., Watanabe, M., Watanabe, K., \& Fujihara, S. (1998). Sex differences in marital and social adjustment. The Journal of social psychology, 138, 26-32.

Folkman, S., \& Lazarus, R. S. (1985). If it changes it must be a process: Study of emotion and coping during three stages of a college examination. Journal of Personality and Social Psychology, 49, 150-170.

Loewenthal, K. M., MacLeod, A. K., \& Cinnirella, M. (2002). Are women more religious than men? Gender differences in religious activity among different religious groups in the UK. Personality and Individual Differences, 32, 133-139.

Maddock, J., Hogan, M., Antonov, A., \& Mastkovsky, M. (1994). Families Before and After Perestroika. New York: Guilford Press.

Matud, M. P. (2004). Gender differences in stress and coping styles. Personality and individual differences, 37, 1401-1415.

Mihić, I., i Zotović, M. (Ur.) (2011). Porodične i profesionalne uloge: značaj zaposlenja za porodično funkcionisanje. Novi Sad: Filozofski fakultet, Odsek za psihologiju.

Mihić, I., Zotović, M., i Petrović, J. (2006). Sociodemografske karakteristike porodice,podela posla u kući i vaspitni stilovi roditelja u porodicama na teoritoriji Vojvodine. Pedagoška stvarnost, 1-2, 118-134.

Nam, S. K., Chu, H. J., Lee, M. K., Lee, J. H., Kim, N., \& Lee, S. M. (2010). A meta-analysis of gender differences in attitudes toward seeking professional psychological help. Journal of American College Health, 59, 110-116.

Nomaguchi, K. M., \& Milkie, M. A. (2003). Costs and rewards of children: The effects of becoming a parent on adults' lives. Journal of marriage and family, 65, 356-374.

Papp, L. M., \& Witt, N. L. (2010). Romantic partners' individual coping strategies and dyadic coping: implications for relationship functioning. Journal of Family Psychology, 24, 551-559.

Petrović, J. (2007). Odnosi u porodicama u Vojvodini: podela uloga, vaspitno ponašanje roditelja i porodična klima. U M. Zotović (Ur.), Porodice $u$ Vojvodini: karakteristike i funkcionalnost. Novi Sad: Filozofski fakultet.

Petrović, J., Mihić, I., Zotović, M., \& Kapor-Stanulović, N. (2009). Family roles of father and mother in the families in the process of transition. Zbornik Matice srpske za drustvene nauke, 31-45. 
Ragsdale, J. D. (1996). Gender, satisfaction level, and the use of relational maintenance strategies in marriage. Communications Monographs, 63, 354369.

Rosario, M., Shinn, M., Morch, H., \& Huckabee, C. B. (1988). Gender differences in coping and social supports: Testing socialization and role constraint theories. Journal of Community Psychology, 16, 55-69.

Rosnati, R., \& Ranieri, S. (2000). Marital relationship in young families: a crosssectional study. Ricerche di psicologia, 24, 39-56.

Šakotić-Kurbalija, J. (2011). Karakteristike bračnog odnosa i traženje psihološke pomoći (Doktorska disertacija). Filozofski fakultet, Univerzitet u Novom Sadu, Novi Sad.

Šakotić-Kurbalija, J. (2016). Bračni odnosi u Srbiji: povezanost kvaliteta, potencijala za razvod i spremnosti za traženje psihološke pomoći. Novi Sad: Filozofski fakultet.

Šakotić-Kurbalija, J., i Kukulj, N. (2016). Povezanost kvaliteta bračnog odnosa i potencijala za razvod sa podelom odgovornosti među partnerima. Šesti kongres psihoterapeuta Srbije: Društvo i psihoterapija. Beograd: 20.10 23. 10. 2016. Savez društava psihoterapeuta Srbije, Zbornik rezimea na CD-u, 20.

Šakotić-Kurbalija, J., Kurbalija D. (2015). Kvalitet bračnih odnosa u Srbiji iz ženskog i muškog ugla. Peti kongres psihoterapeuta Srbije: Ljubav $i$ psihoterapija. Beograd: 22.10 -25. 10. 2015. Savez društava psihoterapeuta Srbije, Zbornik rezimea na CD-u, 134.

Šakotić-Kurbalija, J., Kurbalija D., i Kapetan, A. (2016). Razlike između muškaraca i žena u predikciji potencijala za razvod na osnovu bračnog kvaliteta. Šesti kongres psihoterapeuta Srbije: Društvo i psihoterapija. Beograd: 20.10 -23. 10. 2016. Savez društava psihoterapeuta Srbije, Zbornik rezimea na CD-u, 21-22.

Šakotić-Kurbalija, J., Šanta, I., i Kurbalija, D. (2016). Povezanost strategija suočavanja sa stresom i namere traženja profesionalne psihološke pomoći. Psihijatrija danas, 48.

Šakotić-Kurbalija, J., Trifunović, B. i Zotović, M. (2016). Predikcija namere žena u Srbiji da traže profesionalnu psihološku pomoć. Godišnjak Filozofskog fakulteta u Novom Sadu, 349-365.

Saroglou, V. (2002). Religion and the five factors of personality: A meta-analytic review. Personality and individual differences, 32, 15-25. 
Schmitt, D. P., Realo, A., Voracek, M., \& Allik, J. (2008). Why can't a man be more like a woman? Sex differences in Big Five personality traits across 55 cultures. Journal of personality and social psychology, 94, 168-197.

Schumm, W. R., Resnick, G., Bollman, S. R., \& Jurich, A. P. (1998). Gender effects and marital satisfaction: A brief report from a sample of dual military couples from the 1992 Department of Defense Worldwide Survey of Members and Spouses. Psychological reports, 82, 161-162.

Shek, D. T. (1995). Gender differences in marital quality and well-being in Chinese married adults. Sex Roles, 32, 699-715.

Stone, A. A., \& Neale, J. M. (1984). New measure of daily coping: Development and preliminary results. Journal of personality and social psychology, 46, 892-906.

Tabachnick, B., \& Fidell, L. (2007). Multivariate analysis of variance and covariance. In C. Woods (Ed.), Using multivariate statistics (pp. 375-440). New York: HarperCollins.

Tamres, L. K., Janicki, D., \& Helgeson, V. S. (2002). Sex differences in coping behavior: A meta-analytic review and an examination of relative coping. Personality and social psychology review, 6, 2-30.

Taylor, S., Bennett, F. \& Sung, S. (2010). Unequal but „fair”? Housework and child care in a sample of low to moderate income British couples. Barnett Papers in Social Research 2010-4. Department of Social Policy and Intervention, University of Oxford.

Thompson, L., \& Walker, A. J. (1989). Gender in families: Women and men in marriage, work, and parenthood. Journal of Marriage and the Family,51, 845-871.

Vannoy, D., \& Cubbins, L. A. (2001). Relative socioeconomic status of spouses, gender attitudes, and attributes, and marital quality experienced by couples in metropolitan Moscow. Journal of Comparative Family Studies, 32, 195217.

Veroff, J., Kulka, R. A., \& Douvan, E. (1981). Mental health in America: patterns of help-seeking from 1957 to 1976. New York: Basic Books.

Zuckerman, M., \& Gagne, M. (2003). The COPE revised: Proposing a 5-factor model of coping strategies. Journal of Research in Personality, 37, 169204. 